\begin{tabular}{|ccc|}
\hline & ANNALES INSTITUTI SLAVICI \\
& UnIVERSITATIS DEBRECENIENSIS & \\
SLAVICA XLVII & 2018 & DEBRECEN \\
\hline
\end{tabular}

Adam DROZDEK

\title{
Damaskin Semenov-RudneV: Philosopher And Panegyricist
}

\section{Дамаскин Семенов-Руднев: Философр и панегирист}

В статье представлены философские и богословские взгляды Дамаскина Семенова-Руднева, русского церковного деятеля XVIII века, представленные в его философских тезисах и в проповедях. Она тоже показывает, что его богословие было средством укрепления императорской власти Екатерины II.

Keywords: Damaskin, philosophy, theology, Orthodoxy, panegyrics

When a historical figure is called "one of the most talented representatives of Russian science and of spiritual literature in the age of Catherine II"1, then it is interesting to see what accomplishments led to such a praise.

Dmitrii Efimovich Semenov was born in 1737 in the Tula province. He received some initial education from his father who was a priest. In 1750, he entered the Krutitskaia/Kolomnaseminary and in 1752, the Moscow Slavic-Greek-Latin Academy, where his name was changed to Semenov-Rudnev. After graduation in 1761, he became a tutor in the Kolomna seminary. In 1766-1772, he studied in the University of Göttingen. In 1774, he became a tutor in the Moscow Academy and the next year, its prefect. In 1775, he took monastic vows and assumed the name of Damaskin. In 1778, he became the archimandrite of the Epiphany (Bogoiavleskii) Monastery in Moscow and, the same year, the rector of the Academy. In 1779, he became a member of the Synod. In 1782, he was appointed a bishop of Seversk. The next year, he moved to Nizhnii Novgorod. In 1783, he became a member of the Russian Academy established the same year. Upon retirement in 1794, he moved to the Intercession (Pokrovskii) Monastery in Moscow where he died in 1795.

As a scholar, Damaskin, upon request of Catherine II, presided in 1785 over the creation of a 1000-pages long Dictionary of languages of different peoples, inhabiting in the Nizhnii Novgorod diocese, nominally Russians, Tatars, Chuvashes, Mordvins and Cheremis/Mariand he prepared a grammar of a Mordvinian language (unpublished). He also prepared a 3-volume annotated bibliography of books printed in Russia, of which only parts of the first volume appeared posthumously in print. He prepared three volumes of critical edition of Lomonosov's works and twelve volumes of works of metropolitan Platon. His spiritual works accessible in print are limited to a few sets of philosophical theses, a volume of his sermons and speeches, and

1 Cf. for details in Кратчайшия о Нижнем Новегороде известия, 1791/18: 100-105; МАКАРий [Николай К. Миролюбов], 1857: 160-180; see also his brief autobiography, ГОРОЖАНСКИЙ 1894: 278-279, [Семенов-Руднев], ДАмАскин 1783. 
a small number of separately published sermons. He also translated into German fragments of Nestor's chronicle, Prokopovich' book on the Holy Spirit into Latin, Platon's theology textbook, also into Latin, and a small booklet of Sulzer into Russian.

\section{Philosophical and theological theses}

The Moscow Academy had annual disputations in which two sides participated, one arguing in favor of the presented theses, one against them. In several cases, Damaskin provided the theses for such disputations. In 1776, the theses were as follows: 1. Philosophy is based only on human reason and it is teaching what people everywhere should know. 2. Philosophy should not be a servant of revealed theology; however, philosophical statement should not be contrary to revelation. 3. Adam, Moses, Solomon and others were not genuine philosophers; philosophy in the strict sense began with Aristotle and was perfected only in the $18^{\text {th }}$ century. 4 . Logic shows how to use the powers of reason to arrive at truth. 5. All ideas originate from outer and inner sensations; inborn concepts are inventions of philosophers. 6. Objects outside of us have true existence. 7. Metaphysics teaches about first principles of what humans can know and about concepts concerning existing and possible objects. 8. There are two foundations of human knowledge: the principle of noncontradiction and the principle of sufficient reason; it follows from them that the essence of all things is eternal, necessary, immutable, and independent from reason and will; no duration, even eternal, can exist without succession; the causal chain cannot extend infinitely into the past; no two things are perfectly similar [ГОРОЖАНСКИЙ 1894: 130-133].

Can these theses be considered an expression of Damaskin's own views? This would be impossible to reconcile with his views expressed elsewhere, particularly in his sermons. First of all, Damaskin was hardly a supporter of strict sensualism as advocated in the West by John Locke. He repeatedly stated that humans are born with some values, principles, or concepts that God inscribed in their hearts. In particular, the golden rule and the silver rule are inborn laws and the source of all happiness [ДАМАСКИН 1783: 24]. There is also a common law rooted in the heart of all people to preserve oneself and to increase one's own happiness as much as possible [37].

Strict detachment of philosophy from theology could also be hardly admissible for Damaskin. Philosophy is the domain of human reason, but philosophy never has the last word. After all, there are so many different philosophical systems and only one can be true. Theology that draws on revelation has the last word and, obviously, for an Orthodox ecclesiastic, the Orthodox theology would be the ultimate authority.

The principle of noncontradiction known to the ancients and Leibniz' principle of sufficient reason can go long way in discovering the universal truths. Thus, as stated in 1777 disputation theses, 1 . No one who analyzed material nature can rationally say that there are no immaterial beings. 2 . It cannot be determined how many kinds of immaterial beings exist. 3. It appears that here are two kinds of these beings: God and human soul. From analysis of this world we conclude that God if the Spirit, 
Almighty, infinitely wise and the Creator of all things to manifest His perfections. ${ }^{2}$ We derive the immateriality of the soul from the analysis of thinking, will, and freedom. Reason, however, does not know what awaits the soul after death except that it will be well when it lives "according to its duties and does not waste its powers for evil." Reason does not know when the soul is sent into the body, where it is located in the body and in what way exactly it interacts with the body. 4 . Events of every day testify that, except for God and the human soul, there are other immaterial beings: souls of animals, since animals can have perceptions of things, and good and evil angels. 5. Matter is what is left after form is abstracted from material entities. We do not know the essence of matter; some of its properties include solidity or impenetrability, extension, divisibility, mobility, and weight. ${ }^{3} 6$. Bodies in the world are whole or partial, terrestrial globe being an example of the whole body. 7. Philosophy should teach us how to act in the interest of our true happiness, i.e., for the good state of the body and soul. 8 . Whether human acts are good or evil depends on the law, knowledge of which depends on the will of God. 9. Natural laws obligate all people to preserve ourselves and to spread our well-being and not violate the rights of others [ГОРОЖАНСКИЙ 1894: 134-137].

However, impressive as the scope of knowledge encompassed by philosophy can be, its use of reason is insufficient and powerless to reach what only revelation can provide, and some of them have already been indicated. And thus, as stated in 1780 in another set of disputation theses, 1. Theology explains any type of God worship; theology can be natural, that is, based on reason, or is based on revelation; only one revelation can be right - Christian. 2. Only Old and New Testaments are the true revelation as testified by the church. 3. Some Biblical truths can be known through reason, but not all; natural theology recognizes the following basic principles: God is eternally without change; He created the world and cares for the world and people; there is a great difference between virtues and vices; there is life after death when people will be rewarded for their good works; the human soul is immortal [ГОРОЖАНСКИЙ 1894: 139-141].

There is thus almost imperceptible transition from philosophy and metaphysics to natural theology, all based on human reasoning powers. They can state a great deal about the principles of the universe and about its Creator, but they cannot say everything that is needed for human life and, more importantly, the afterlife. Rational knowledge does not satisfy all human needs, except for some intellectual needs. In particular, natural religion, which is the religion based on human reason [ДАМАСКИН 1783: 228], and thus which can be equated with natural theology, does not calm conscience nor violent people [78]. That is, rationality alone - philosophy

2 As stated in the opening 1775 disputation thesis, "God exists and he is a being that has existence in himself that does not depend on anything else, [being that is] immutable, indivisible and supremely perfect so that it has not only all possible perfections, but also [perfections] perfect to the greatest possible extent or, better yet, [perfections] without any levels," [Дмитрий СЕменов 1775]; Юрий Н. Солонин, Русское духовенство и русское просвещение XVIII века (еп. Дамаскин, Семенов-Руднев), in: [ЗАмАЛЕев 2001, 338-339].

3 Cf. the third 1775 disputation thesis. 
along with natural theology/religion - has serious limitations. The best means of consolation in times of distress are the ones which create the hope of happiness, and this can be found only in the Gospels; reason and philosophy are not successful here [155]. Human reason speaks about God's perfections, His uniqueness, and the order in His creation stemming from His wisdom [228]; however, it cannot fathom all divine perfections [231]. For instance, the mystery of the Trinity and of the incarnation of Christ are beyond its reach [232]. No philosophy, no teaching, is comparable to Christianity in respect to goodness and to morals [233-234].

Human reason is able to make statements about virtues, reward for good deeds, and punishment for evil - all of which is strengthened and shown in true light by Christian revelation [ДАМАСКИН 1783: 228]. The main teaching of Christianity is that man is sinful and is justified before God by his belief in Christ and this teaching can be found in the Old Testament in the form of prophecy about the coming of the Messiah [229]. Through Christ we become without sin and sons of God and we are not afraid of death [162]. God justifies only those who believe in Christ who gave Himself as an offering to God for our sins [193].

Human reason is certainly not omnipotent: it cannot grasp all the truths about the natural world [ДАМАСКИн 1783: 231], all the less the truths of the higher order. Reason has to be followed by revelation. However, even this fact does not leave humans in the epistemological clear. As Damaskin stated, there are many revelations contrary to one another. "This incompatibility of revelations in the past and today is the cause of great difficulty and confusion in knowing which one is false" [226]. Aren't we, he asked, deluding ourselves by siding with Christianity? In the spirit of his times, Damaskin stressed the role of the natural law: this law gives some idea of God, but this idea is allowed to shine fully only through Christian revelation $[132,228$, part 2, 12].Damaskin also used a traditional argument in favor of Christianity: the life of Christ. Christ led an exemplary life, the life without sin in line with what He preached, unlike supporters of other revelations [134]. Also, His miracles showed the real power of His salvific message that did not only speak about the afterlife, but this life as well [136, 234, part 2, 17]. Moreover, there are many prophecies which were fulfilled in Christ's life and only God could make prophecies that were later fulfilled [134, 213-214, 233, part 2, 15]. Thus, Christianity is the right religion. However, even this statement could not remain unqualified. The best religion is Christianity, but only "such Christianity that is not polluted by wrong interpretations, superstition, and greed. Such Religion is more similar to the enlightened reason and more in agreement with the natural worship of God" [79]. It remains to be seen in what respect Christianity is more in tune with enlightened reason and natural worship than any other religion. However, the listener of the sermon could guess what Damaskin meant by correct interpretation and avoidance of superstitions: the Orthodox Christianity, and only officially recognized Orthodoxy with the exclusion of Old Believers. Of course, Catholicism and Protestantism were also excluded.

Although most of Damaskin's messages are in a rather ecumenical spirit, he was an Orthodox ecclesiastic, after all, and could not refrain himself from jabs against non-Orthodox confessions. For example, he said that there are some rites introduced 
by Christ, some by apostles, and some by the church, the latter of lesser importance than Christ's and the apostles' [246]. These rites are different in different countries and in different times; they changed even in Russia, to mention the contested Nikon's reform, but a private person cannot modify the rites of "our church" [ДАМАСКИН 1783: 247]. This sounds like a mild permission to adjust rites to local needs; however, when discussing the problem whether leavened or unleavened bread should be used in communion, in his opinion, the West got it wrong and the Greek side is right (259; cf. the fourth 1779 theological thesis [ГОРОЖАНСКИЙ 1894: 138]) and so is the Russian church: "we should be always careful in changing ancient church customs so that we do not deserve shame which the Romans [Catholics] deserved" [ДАМАСКИН 1783: 260].

Most of the disputation theses appear to represent Damaskin's own views, but not all of them. They were, after all, theses presented for disputation as deemed philosophically and theologically interesting or important, not as summaries of Damaskin's views. Otherwise, a conclusion can be made that he was a follower of John Locke's sensualism which "sometimes put him outside the boundaries of ChristianOrthodox theology." [КузНЕцОВ и др, 1998, 56; Титков, 2005, 137] It is rather this theology which should be a guide in deciding if particular theses expressed Damaskin's philosophy. Since the sensuality thesis was given in 1776 and the clear endorsement of innatism was given in sermons of 1777 and 1778, it would be difficult to see how Damaskin could have made contradictory philosophical pronouncements so carelessly at about the same time. Also, rejection of innatism would mean a rejection of the patristic tradition on that point: for instance, Chrysostom spoke about the natural law being implanted in man by God from the very beginning (Concerning the statutes $12.9,11,12,15 ; 13.7)$, and thus Christ with His pronouncements did not contradict the natural law He deposited in human nature (13.7) and neither did Paul's teachings that "tightened the links of nature" (Basil, Hexameron 9.4).

As it can be concluded from Damaskin's scattered remarks, innatism supported by rationality appears to be the foundation of his philosophico-theological views. There are inborn laws and concepts which lead to some understanding of God and this understanding is enlightened and fortified by Christianity. The latter is validated by the sinless life Christ, by His miracles and by prophecies fulfilled in Him. The proper version of Christianity can be found only in Russia's official church because it has its roots directly in apostolic teachings. Never mind the irony of the fact that Old Believers separated themselves from the official church because it modified some of its rites. 


\section{Personal salvation}

Why is a person born into this world? Job says, to work [trud 5:7] [ДАМАСКИН 1783: 84]. ${ }^{4}$ Many people ignore it in their lives of idleness and entertainment [85]. However, those who devote too much attention to entertainment miss out on their purpose in this world and reward in the next [92]. Entertainment causes our preoccupation with earthly things, not spiritual [94]. Entertainment takes time that can be devoted to something else and causes indifference to piety [97]. An account will be given for the waste of time [101]. Man has to suffer much during his life, and, unlike animals, he is afraid of death; "if man came to this world only for happiness in this world, he would be most miserable among all living beings" [120]. Man is able to reason, to think about the future. Animals have to follow their inborn instincts [121]. Man's needs grow with his knowledge. Dissatisfied with earthly things, his desires are directed toward heaven. The limitlessness of human desires means that "man comes to earth not for what is here ... but for the pleasure and peace determined for him in this side of life where he is almost always dragged by his unlimited desires even against his will" [122]. It can be observed that many godless people live comfortable lives; their plans succeed, but many God-fearing people lead hard lives; this is contrary to divine justice [123]. However, the more godly people suffer, the better will be their reward in the afterlife. This is a common sense proof of the afterlife [124]. In fact, suffering is a means to bring us there [156]. The revelation assures us that God cares for us [125]; the suffering in this world is nothing in comparison with the blessing in the afterlife where happiness awaits us [126]. Thus, regardless of the quality of life, people's minds should be directed to the afterlife since from the other-worldly perspective any discomfort of the life on earth is of negligible magnitude, and awareness of this fact greatly helps in living through all the uncertainties of life. In a word, the essence of this life is the afterlife. This life causes sadness, but "we will eat its salvific fruits. Is it much to suffer for twenty of thirty years if we know that we will live eternally in all contentment?" [158].

\section{Social issues}

Social issues were very close to Damaskin's heart and when expressing his concerns for social and national unity, he tried to cast them in universal moral terms.

In his view, the golden rule as expressed in Biblical words "as you want that people do to you, do the same to them" [Lk. 6:31], is the foundation of the teaching without which no throne can last, and no nation nor any person can be happy [ДАМАскин 1783: 2]. The sentiment expressed in these words is a major virtue of any citizen and any ruler, the virtue that can be called the love of the fatherland [3]. This love is simple, unenlightened, and it stems from an inborn impulse: it loves what is close to it; it respects only people from the same nation; others are counted as nothing [4], but without it no nation would last [5]. However, this is not enough,

4 Cf. митрополит Платон: Поучительныя слова, vol. 5, Москва 1780: 90. 
particularly in "our better and most enlightened times." Enlightened people need noble, enlightened love. A person loves another person not because of living in the same land, but because of being a human being [6]. The true lover of the fatherland is motivated only by the love of goodness [11]. He wants all people to be happy even those who hate him [12]; he loves all people, including his enemies. Thus, love of people is a true source of love of the fatherland [13]. "Just citizen, ... although he looks only for the happiness of his Fatherland, he does not diminish the well-being of another nation nor does he violate the rights of another society ... Sciences, wisdom, freedom, good morals, and abundance, these true treasures of living together, multiply and spread only in this nation which does not violate the well-being of its neighbors" [14].

This social message has religious underpinnings. God created us rational so that we can do as much good as possible. God put this law in the hearts of "more simple people" in the clearest way possible [ДАМАСКИН 1783: 23]. An inner voice calls us to do to others what we would like them to do to us (the golden rule) and not do to others what we would like them not to do to us (the silver rule). This inborn law is the source of all our happiness [24]. All human actions should be directed toward the achievement of inner and outward peace. We live in society to help one another - and this is the reason that society exists. Only a virtuous person can be a good citizen [25].

The principal duty of a citizen is considering of the Most High Being. People should get to know His infinite perfection, praise His reason and will, and rely on His infinite design and providence. This is because, as stated in the second 1775 disputation thesis, God created the best of all possible worlds and $\mathrm{He}$ "protects and directs it so that nothing without His providence happens and or can happen in it." The citizen should always think about "the other side of the grave" where he will be rewarded for his good deeds [ДАМАСКИН 1783: 27]. To reach the future happiness, he should first know himself and his needs, teach his will always to choose good, know how to counter his own passions, fortify himself through virtue against the evil of this world, and always keep in mind the benefit of the union with God and people [28]. Also, seeing the well-being of other nations due to science, "he respects and loves it as the most valuable gift sent from heaven" [31].

These wonderful universalist sentiments are very quickly quenched when Damaskin tried to express them in the way they should manifest themselves among the $18^{\text {th }}$ century Russian citizenry.

God is in control of all things, so He is in control of who is the ruling monarch. In fact, monarchs should be considered His anointed, His providential choices for the good of the people. Consequently, a citizen should be an obedient subject of whoever is on the throne, thereby expressing his trust in God's providence. And thus, he applies his talents for the common good and submits himself to the laws of society and to those who enforce them [ДАМАСКИН 1783: 33]. He should even submit to the will of a tyrant and hate rebellions [34]. And again, there are no rebellions, no robbers in enlightened nations, even if people see lawlessness of the authorities [74]. Obedience to the authority, any authority, becomes the sign of political maturity of a nation and of an enlightened stage that it reached. In this, Damaskin implicitly 
subscribed to the view voiced decades earlier by Prokopovich that the monarch is responsible only before the Almighty, not before the citizenry.

What makes society strong is justice [ДАМАСКИН 1783: 38]. Justice elevates a nation, sin makes it small [Prov. 14:34] [39]. People got together to do together what one person could not accomplish and so villages and cities have been built. Love and friendship should rule among people to maintain the union of society [40-41]. And if self-interest can violate the common good, then the latter should be chosen over the former. ${ }^{5}$ Justice says that we are all equal by nature, that we love one another to live together in peace as the creation of the same God. Why would that be important? Because of happiness? Not quite, because such justice causes a nation to be united, thus strong, thus great [42-43]. In this way, the grand prerequisite of social justice leads to a rather crude conclusion concerning the greatness - political, military, possibly also cultural - of the nation, the Russian nation, that is. Incidentally, one reason why Damaskin chose Sulzer's booklet for translation into Russian was that he argued why Greek and Roman classic should be taught in the schools: one reason was to learn that "the citizens of one city were incomparably more closely united than they are today. Common good lied in their hearts more [than today]; their association was not due to any compulsion, no unneeded and vain ostentation and not tasteless ceremony."

As to the social structure, in the course of historical development, people agreed to elect from among themselves those responsible for works in the interest of society [ДАМАСКИН 1783: 43-44]. Should we assume that somehow in this election process the hand of God intervened so that the right people are chosen for the right positions? Otherwise, the position of the authorities becomes precarious since it would be guaranteed only by the whims of the populace, not by divine authority. Moreover, when was a person elected by the will of the people to the Russian throne? Surely not Catherine [Сf. КУзНЕЦОВ и др. op. cit. 95]. If a society is blossoming, this is a sign of God's blessing; if it is in a poor condition, this is a sign of God's wrath. The wellbeing of society is recognized by wise mayors, skillful generals, perspicacious politicians, good shepherds of human souls, and a wise supreme ruler [ДАМАСКИН 1783: 54-55]. Supreme authority is as much needed for a nation as the soul is needed for the body, since nothing could properly function without it [56].

The sovereign should try to multiply his nation, spread sciences and arts, improve the morals of the nation with most humane means, care for the health of the population, improve material well-being of people by promoting mercantilism and agriculture, put competent people on various posts, try not to provoke neighboring nations, but "when any of it tries to violate the peace of his nation, he should by the national law reverse that by the gentlest and not destructive ways. In a word, he should be the father of his nation" [ДАМАСКИН 1783: 66-67].

5 Cf. митрополит Платон: Поучительныя слова, vol. 3, Москва 1780: 36-37.

6 [Johann Georg Sulzer], Gedanken über die beste Art die claßischen Schriften der Alten mit der Jugend zu lesen, Berlin: Christian Friedrich Voß 1765, p. 13; [Иоганн Георг Зульцер], О полезном с юношеством чтении древних классических писателей, Санкт-Петербург 1774, p. 14. 
All these lofty statements about civic virtue, happiness of people, and social justice are quickly reduced to civic obedience of authorities to deteriorate altogether into overwrought praises of the empress Catherine.

\section{Catherine II}

The true example of the love of the fatherland is in the empress, as manifested in her laws and "alliances made with the neighboring nations" [ДАМАСКИН 1783: 15]. People have a model of a good citizen in their empress. She cares about spreading virtue (35). Since her ascension to the throne, Catherine does not think about anything else but about preservation of justice in the nation [49].

In praising her Nakaz, "all these laws processed by her own mind and hands" [50], Damaskin never mentioned that most of it was plagiarized from Montesquieu, even by her own admission.

On the international scene, there was no one better. The true victor is who deals with the enemy like a father with his children he loves; he spares their lives and houses and is loved even by the enemy. Catherine is an obvious example of such a victor. "Have there been in Russia enemies with whom were dealt with mercy rather than with strong measures?" Enemies outside Russia whom she conquered she treated "always and everywhere with meekness, pity, unprecedented mercy, generosity and returning them places conquered with the Russian arms." [ДАмАскин: 1792: 5-6] Damaskin overlooked the fact that in 1792, when he said that, Poland was after the first partition and within three short years two more partitions would destroy it as an independent country. Was this an example of her meekness accompanied with the return of Polish territories? He never mentioned the annexation of Crimea in 1783, either, nor the annexation of the Yedisan territory after the two wars with the Ottoman empire. No thought about returning them to Turkey.

There are enemies in us, our passions. All her life Catherine conquered "the inner enemies ... through her faith and piety." "Shame on you all who think that She is evil!" [ДАМАСКИН 1792: 7, 9] Catherine never quite made a secret of her interminable string of lovers. Was this a way of conquering her passions? Why would a priest consider it shameful if anyone would criticize it? No one in the autocratic monarchy, of course, did, at least not in public.

In Damaskin's mind, Catherine introduced a very wise way of managing church properties [ДАМАСКИН 1787: 9]. Catherine secularized church properties - which amounted to their confiscation - which was hardly opposed by churchmen who, like Damaskin, praised it as an expression of her, and thus divine, wisdom, or they simply kept silent. Matseevich was a rare example of courageous opposition, which, in 1764, ended in his defrocking an exile to Revel/Tallinn.

Not only is she a paragon of civic virtues, but also a model Christian: "We have solid and unshakeable pillar and foundation (столп и основание) of the Christian faith, YOU, Most Virtuous Sovereign!" [ДАМАСКИН 1783: 141], and again, "We have a firm and unshakeable pillar of Christian faith in You, Most Pious (Благочестивейшая) Sovereign!” [part 2, 22], in which Damaskin appears to allude to the Biblical statement that the church is the pillar and foundation of truth 
[1 Tim. 3:15]. In a way, it was justified: after Peter's church reform, the emperor/empress was, technically, the head of the church and Catherine called herself as such on several occasions. However, still, identifying the church with Catherine should give a pause to an ecclesiastic. And yet, he pressed on by stating that "If one could represent God in human form, I don't know who, except for HER among mortals would be more appropriate to be called God dwelling in flesh." [ДАМАскИн 1787: 11. $]^{7}$ Having seen her as divine figure it is no surprise that Damaskin stated that people should obey her "sacred laws" without exception [ДАМАСКИН, 1791: 8.].

In all this, the only conclusion Damaskin could reach was that all Catherine's orders should be followed eagerly without sparing one's life [ДАМАСКИН 1783: 102]. And so he praised for all she did, deservedly - like for her positive impact on the development of education, arts, and science - and otherwise. In this, Christian faith, even of a priest, even "one of the most talented representatives of Russian science and of spiritual literature in the age of Catherine II," became subservient to the will of a monarch.

\section{Bibliography}

SUlzER 1765: Sulzer, Johann Georg, Gedanken über die beste Art die claßischen Schriften der Alten mit der Jugend zu lesen, Berlin: Christian Friedrich Voß.

ГоРОЖАНСКИй 1894: Горожанский, Яков И. Дамаскин Семенов-Руднев, епископ Нижегородский (1737-1795): его жизнь и труды, Киев: Типография Г.Т. Корчак-Новицкаго.

ДАмАскин 1787: Семенов-Руднев, Дамаскин, Слово похвальное на всерадостное торжество о вступлении на всероссийский престол ... Екатерины, Нижний Новгород: Типография Нижегородского наместнического правления.

ДАмАСкин 1775: Семенов-Руднев, Дмитрий, Положения философическія изъ богословіи, естественной физики и нравоучительной философии для публичных диспутовв Московской академии июля дня, 1775 года бывших, Москва.

ДАмАскин 1783: Семенов-Руднев, Дамаскин, Проповеди, Москва: В Университетской Типографии, у Н. Новикова.

ДАмАскин 1791: Семенов-Руднев, Дамаскин, Слово о великодушии, Нижний Новгород: ТипографияНижегородского наместнического правления.

ДАмАскин 1792: Семенов-Руднев, Дамаскин, Слово в высокоторжественный день возшествия на Всероссийский престол ... Екатерины, Санкт-Петербург: Типография Свящейшаго Правительствующаго Синода.

ЗАмАЛЕЕВ 2001, Замалеев, Александр Ф. (ed.): Русская философия: новые исследования и материалы: проблемы методологии и методики, Санкт-Петербург: Издательско-торговый дом “Летний сад”.

ЗульцЕР 1774: Зульцер, Иоганн Георг, О полезном с юношеством чтении древних классических писателей, Санкт-Петербург.

Кратчайшия о Нижнем Новегороде известия: Древняя российская вивлиофика, Москва: В Типографии Компании Типографической 1791: 18/72-147.

7 These words "are rather strange, not to say more [about them], in the mouth of an ecclesiastic orator [spoken] from the church pulpit" [ГОРОЖАНСКиЙ 1894: 273].

DOI: $10.31034 / 047.2018 .09$ 
КузНЕцОВ 1998: Кузнецов, Евгений В., Никулин, Игорь Н., Титков, Евгений П., Епископ Нижегородский и Алатырский Дамаскин: страницы жизни, деятельности, творчества, Арзамас: Арзамасский госсударственный педагогический институт им. А.П. Гайдара.

МАКАРИЙ 1857: Макарий Николай К. Миролюбов, Дамаскин Рудневъ, Епископ Нижегородский и Алатырский (1784-1794), История нижегородской иерархии, Санкт-Петербург: Издание книгопродавца Н. Г. Овсянникова, 160-180.

Митрополит Платон: Поучительныя слова, vol. 5, Москва 1778-1806, vols 1-20.

ТиткОв 2005: Титков, Евгений П., Подвижник российского просвещения (творческий путь епископа Дамаскина), Арзамас: АГПИ.

Adam DROZDEK

Duquesne University

Pittsburgh, USA

drozdek@duq.edu 